\title{
DAPHNIA MAGNA ACUTE IMMOBILIZATION TEST: AN OPPORTUNITY TO TEST THE ECOTOXICITY OF ALTERNATIVE FUELS
}

\author{
KatAlin ESZTER HUBAI*1 \\ ${ }^{1}$ Center for Natural Sciences, University of Pannonia, Egyetem u. 10, 8200 Veszprém, HUNGARY
}

The increasing need for environmental protection has led to the development of alternative biofuels. While the use of alternative fuels has significantly increased recently, only a few studies have addressed the problem of their ecotoxicity. The main aim of this work was to provide a short review of the Daphnia magna acute immobilization test, which has been the most commonly discussed in the literature.

Keywords: Daphnia magna, immobilization, ecotoxicology, alternative fuels

\section{Introduction}

Over recent decades, rapid population growth has been accompanied by a growth in the consumption of energy and use of transport fuels, which has caused irreversible environmental degradation and climate change [1]. Desires for a green environment have increased the demand for alternative fuels which in turn has necessitated researchers and industries to develop renewable alternative and cleaner energy sources worldwide [2].

Biofuels are energy-enriched substances manufactured from vegetable oils, recycled cooking grease and oil as well as animal fats through a chemical process known as transesterification, which is described below, to produce chemical compounds known as fatty acid methyl esters (FAME) [3,4]. Biodiesel is the name given to these esters when they meet biodiesel standards such as the American ASTM D6751 or the European EN14214 for use as transport fuels [4]. Biodiesel is an eco-friendly form of fuel and may provide a solution to some problems associated with petroleum diesel [5].

Alternative fuels are key to improving the EU's security of energy supply, reducing the impact of transportation on the environment and boosting the EU's competitiveness. They are also an important building block for the EU's transition towards a low-carbon economy. In 2007, the production of biofuels in the EU reached 8,500 ktoe (kilotonnes of oil equivalent), while in 1996, this figure was less than 500 ktoe [6]. In 2010, $15.5 \%$ of power generation and $1.3 \%$ of energy consumption worldwide was attributed to renewable energy, while today, it is estimated that $86,000 \mathrm{kt}$ per year of biofuels are produced, with the USA and Brazil being the primary producers [7].

\footnotetext{
*Correspondence: hubai.katalin@mk.uni-pannon.hu
}

More studies have shown that the use of biodiesel would reduce emissions of hydrocarbons, carbon monoxide and volatile organic compounds [8,9]. However, the results of analyzing the biological effects related to the presence of biodiesel in the environment are ambiguous [10].

Although the use of alternative fuels has significantly increased recently, relatively few studies have addressed the problem of their ecotoxicity. Therefore, the main objective of this study is to provide a short overview of the Daphnia magna acute immobilization test which has been the most frequently discussed in the literature.

\section{Methodology}

\subsection{Test organism}

In addition to the chemical characterization of a substance, ecotoxicological tests provide an important tool for ecological risk assessments [11], giving a quantitative estimation of the overall toxic effect of the test organisms selected [12]. In general, the Daphnia magna acute immobilization test is amongst the most widely used ecotoxicological methods [13]. International standards apply such as OECD 202:2004 [14] or ISO 6341:1996.

The test organisms are the freshwater crustaceans $D$. magna and $D$. pulex. For the tests, neonates (newborn, freshly hatched juveniles) are used. (The main purpose of any standard protocol is to increase quality assurance which in turn might increase the credibility of the data produced [15]. In order to minimize any possible errors caused by improper maintenance of stock cultures, so-called Toxkits have been developed and marketed by MicroBioTests Inc. (Mariakerke-Gent, Belgium) [16]. The main benefits of using a Toxkit are that they are maintenance-free and user-friendly [17] test organisms 


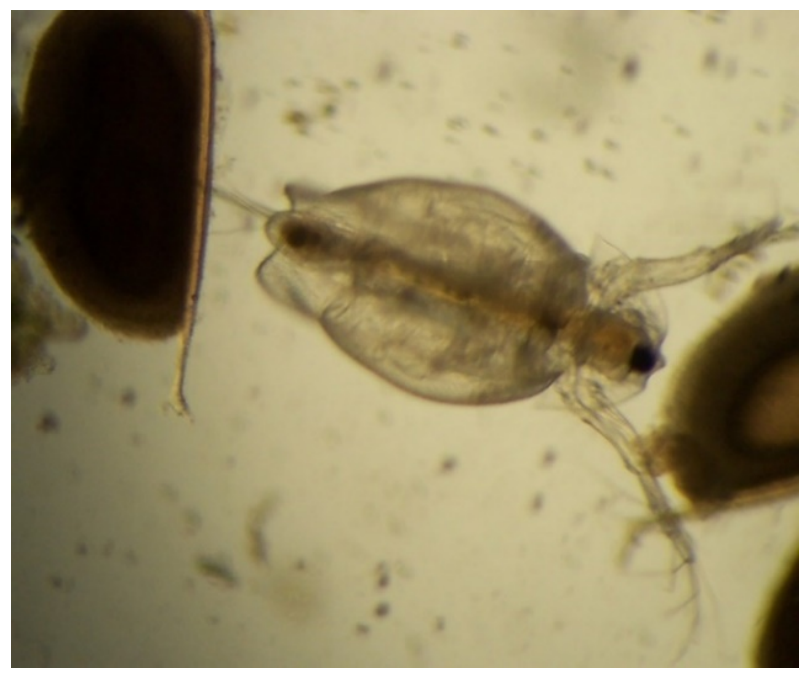

Figure 1: Freshly hatched D. magna neonate

whose genetic material is practically uniform and, prior to testing, juveniles of approximately the same age are reproduced (Fig. 1).

\subsection{Implementation of experiments}

There are several options for conducting alternative fuel toxicology studies. In one part of the research, the fuel was stirred in water before the test organisms were introduced into the test chamber [18-20]. In this method, the layer of oil on the top of the wells can cause some problems.

In other experiments, aqueous extracts were used, for example, a stock solution was made by adding seawater (depending on the test organism) to the sample and stirring the mixture for $10-24 \mathrm{~h}$ [21-23].

Three different biodiesels, that is, two based on the vegetable oils produced by canola and soybean as well as waste frying oil that originated from animals, were used by Hollebone et al. [24]. Oil-in-water dispersions (OWD) and water-accommodated fractions (WAF) were used for the Daphnia magna assay. Different results were observed during the tests; higher LC50 values were measured in WAFs compared to in OWDs. This suggests that the soluble fraction is of lower toxicity compared to the physical danger of the organisms being smothered by the oily fuel (See Table 1).

Müller et al. [23] assessed the toxicity of the watersoluble fraction (WSF) of biodiesel on D. magna in comparison to the WSF of diesel [24]. The tested sample of biodiesel was a fatty acid methyl ester (FAME) mainly produced by soybean oil $(95 \%)$. This biodiesel did not elucidate a measurable degree of toxicity either following acute or chronic exposure. On the other hand, in a study by Eck-Varanka et al. [21], the ecotoxicity of a rapeseed biodiesel was profiled using a battery of test organisms and D. magna exhibited an extremely high degree of toxicity, being the most sensitive assay in the battery.
Khan et al. [18] carried out an extensive study to compare the ecotoxicity of diesel, neat biodiesel (B100) and blends of both (B50, B20 and B5). B100 was produced from recycled cooking oils and fats. The lowest and highest levels of ecotoxicity were exhibited by B100 and diesel, respectively, while the ecotoxicity of the blends, expressed both in terms of mortality rates and EC50 values, were in the intermediate range. However, the differences between the measured responses were quite small: the LC50 values of Daphnia magna in neat biodiesel and diesel were 4.65 and 1.78 ppm, respectively. Tjarinto et al. (2014) conducted a similar study on biodiesel produced from waste vegetable oil and reported an EC5 value of $3.157 \mathrm{ppm}$ for Daphnia magna [25].

Heger et al. [26] compared the ecotoxicity of two biofuel candidates (1-octanol and 2-butanone) and found that 1-octanol exhibited a significant level of ecotoxicity on D. magna while 2-butanone did not. However, assays conducted on other test organisms revealed that the metabolites of the tested products could pose a higher risk of toxicity. Heger et al. [27] applied the D. magna acute immobilization test to compare the aquatic toxicity of the two biofuel candidates, namely 2-methyltetrahydrofuran (2-MTHF) and 2-methylfuran (2-MF), and found that the latter induced a significantly higher mortality rate than 2-MTHF (See Table 1).

Ecotoxicity, more precisely the ecotoxicity impact, is also included in the life cycle assessments (LCA) of alternative fuels [28]. Since LCAs follow the whole production line of a product, Bunzel et al. [29] used a D. magna assay to evaluate pesticide runoff from agricultural fields used for the cultivation of energy crops.

Khan et al. [18] stressed that one possible major purpose of ecotoxicity testing is assessing the potential risk of fuel spills in aquatic ecosystems. As such, it should be emphasized that Daphnia magna, being a freshwater taxon, cannot represent marine ecosystems, instead marine surrogates are used such as the brine shrimp Artemia salina [30].

Gateau et al. [31] investigated water-soluble fractions (WSFs) of four different vegetable oil methyl esters. Lower EC50 values ( $>1000 \mathrm{mg} / \mathrm{L}$ ) were calculated for vegetable oil methyl esters than for regular diesel $($ EC50 $<100 \mathrm{mg} / \mathrm{L})($ See Table 1)).

The toxicity of biodiesel blends and crude oils have been investigated in other studies and biodiesel has been found to be less toxic to D. magna than both the biodiesel blends and crude oil (See Table 1).

\section{Conclusion}

In conclusion, it should be emphasized that the number of available studies is surprisingly low. Furthermore, these studies are extremely difficult to compare due to the following reasons: since the studies have been conducted on alternative fuels of very different origins, more extensive research on their chemical compositions to determine potential toxic effects is required. By taking into consid- 


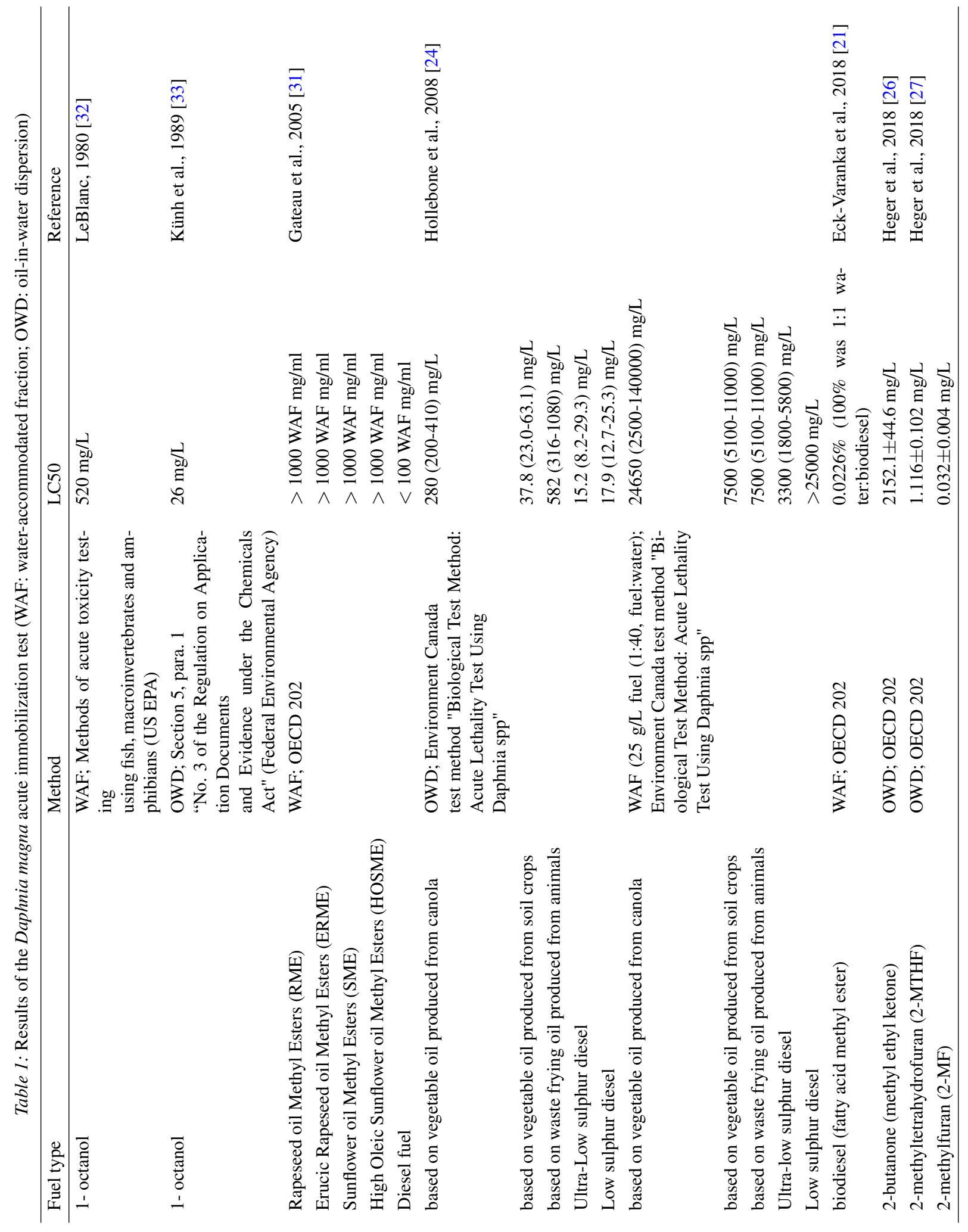


eration the practical aspects of the tests, different periods of exposure have been employed (chronic exposures of 24,48 and even $96 \mathrm{~h}$ ). Sample preparation protocols also differ: oil-in-water dispersions (OWD) and wateraccommodated fractions (WAF) have also been used as alternatives [34].

Generally, the Daphnia magna acute immobilization tests show an appropriate degree of sensitivity to a wide variety of compounds or complex mixtures [35-37]. However, as different components of an ecosystem will exhibit taxon-specific sensitivity to a chemical, a carefully composed battery of biotests should be used to gain a more comprehensive understanding [38]. It is possible that these tests will represent different functional and/or taxonomic groups as the ecotoxicity of pollutants influences the function and structure of aquatic or terrestrial ecosystems [39], moreover, possible endpoints will differ [40]. The minimum battery should involve the luminescent bacteria test, algae and zooplanktonic crustaceans [41].

\section{Acknowledgments}

This study was funded by the NTP-NFTÖ-19-B-0148 project.

\section{REFERENCES}

[1] Darda, S.; Papalas, T.; Zabaniotou, A.: Biofuels journey in Europe: Currently the way to low carbon economy sustainability is still a challenge, J. Clean. Prod., 2019, 208, 575-588 DOI: 10.1016/j.jclepro.2018.10.147

[2] Shote, A.S.: Biofuel: An environmental friendly fuel, in Anaerobic Digestion, Eds.: Banu, J.R. (Intech Open, London, England), 2019. DOI: 10.5772/intechopen.82856

[3] Alleman, T.L.; McCormick, R.L.: Biodiesel handling and use guide, Fifth Edition (U.S. Department of Energy), 2016, DOE/GO-102016-4875

[4] Milbrandt, A.; Kinchin, C.; McCormick, R.: The feasibility of producing and using biomass-based diesel and jet fuel in the United States, Technical Report NREL/TP-6A20-58015, 2013. DOI: 10.2172/1260324

[5] Aransiola, E.F.; Ehinmitola, E.O.; Adebimpe, A.I.; Shittu, T.D.; Solomon, B.O.: Prospects of biodiesel feedstock as an effective ecofuel source and their challenges, in Woodhead Publishing Series in Energy, Advances in Eco-Fuels for a Sustainable Environment, Eds.: Azad, K. (Woodhead Publishing, Sawston, England), 2019. ISBN: 978-0-081-02728-8

[6] European Commission (2014): Report on the Assessment of the Member States National Policy Frameworks for the development of the market as regards alternative fuels in the transport sector and the deployment of the relevant infrastructure pursuant to Article 10 (2) of Directive 2014/94/EU, https://ec.europa.eu
[7] Rastogi, M.; Shrivastava, S.: Recent advances in second generation bioethanol production: An insight to pretreatment, saccharification and fermentation processes, Renew. Sust. Energ. Rev., 2017, 80, 330-340 DOI: 10.1016/j.rser.2017.05.225

[8] Makareviciene, V.; Janulis, P.: Environmental effect of rapeseed oil ethyl ester, Renew. Energy, 2003, 28(15), 2395-2403 DOI: 10.1016/S0960-1481(03)00142-3

[9] Bamgbose, I. A.; Anderson, T.A.: Phytotoxicity of three plant-based biodiesels, unmodified castor oil, and Diesel fuel to alfalfa (Medicago sativa L.), lettuce (Lactuca sativa L.), radish (Raphanus sativus), and wheatgrass (Triticum aestivum), Ecotoxicol. Environ. Saf., 2015, 122, 268-274 DOI: 10.1016/j.ecoenv.2015.08.003

[10] Hawrot-Paw, M.; Izwikow, M.: Ecotoxicological effects of biodiesel in the soil, J. Ecol. Eng., 2015, 16(5), 34-39 DOI: 10.12911/22998993/60451

[11] Klimkowicz-Pawlas, A.; Maliszewska-Kordybach, B.; Smreczak, B.: Triad-based screening risk assessment of the agricultural area exposed to the long-term PAHs contamination, Environ. Geochem. Health, 2019, 41(3), 1369-1385 DOI: 10.1007/s10653018-0220-y

[12] Kessler, N.; Schauer, J.J.; Yagur-Kroll, S.; Melamed, S.; Tirosh, O.; Belkin, S.; Erel, Y.: A bacterial bioreporter panel to assay the cytotoxicity of atmospheric particulate matter, Atmos. Environ., 2012, 63, 94-101 DOI: 10.1016/j.atmosenv.2012.09.048

[13] Allan, I.J.; Vrana, B.; Greenwood, R.; Mills, G.A.; Roig, B.; Gonzalez, C.A.: A "toolbox" for biological and chemical monitoring requirements for the European Union's Water Framework Directive, Talanta, 2006, 69(2), 302-322 DOI: 10.1016/j.talanta.2005.09.043

[14] OECD/OCDE, 2004. OECD Guideline for Testing of Chemicals No. 202: Daphnia sp. Acute Immobilisation Test. ISSN: 20745761 OECD (2004), Test No. 202: Daphnia sp. Acute Immobilisation Test, in OECD Guidelines for the Testing of Chemicals, Section 2, (OECD Publishing, Paris) DOI: 10.1787/9789264069947-en

[15] Koëter, H.B.W.M.: Mutual acceptance of data: harmonised test methods and quality assurance of data - the process explained. Toxicol. Lett., 2003, 140141, 11-20 DOI: 10.1016/S0378-4274(02)00491-5

[16] Persoone, G.; Baudo, R.; Cotman, M.; Blaise, C.; Thompson, K.Cl.; Moreira-Santos, M.; Vollat, B.; Törökne, A.; Han, T.: Review on the acute Daphnia magna toxicity test - Evaluation of the sensitivity and the precision of assays performed with organisms from laboratory cultures or hatched from dormant eggs, Knowl. Managt. Aquatic Ecosyst., 2009, 393, 01 DOI: $10.1051 / \mathrm{kmae} / 2009012$

[17] Kokkali, V.; van Delft, W.: Overview of commercially available bioassays for assessing chemical toxicity in aqueous samples. Trends in Anal. Chem., 2014, 61, 133-155 DOI: 10.1016/j.trac.2014.08.001 
[18] Khan, N.; Warith, M.A.; Luk, G.: A comparison of acute toxicity of biodiesel, biodiesel blends, and diesel on aquatic organisms. J. Air Waste Manag. Assoc., 2007, 57(3), 286-296 DOI: 10.1080/10473289.2007.10465333

[19] Bamgbose, I.A.; Anderson, T.A.: Assessment of three plant-based biodiesels using a Daphnia magna bioassay. Environ. Sci. Pollut. Res., 2018, 25(5), 4506-4515 DOI: 10.1007/s11356-017-0678-7

[20] Pikula, K.S.; Zakharenko, A.M.; Chaika, V.V.; Stratidakis, A.K.; Kokkinakis, M.; Waissi, G.; Rakitskii, V.N.; Sarigiannis, D.A.; Hayes, A.W.; Coleman, M.D.; Tsatsakis, A.; Golokhvast, K.S.: Toxicity bioassay of waste cooking oil-based biodiesel on marine microalgae. Toxicol. Rep., 2019, 6, 111-117 DOI: 10.1016/j.toxrep.2018.12.007

[21] Eck-Varanka, B.; Kováts, N.; Horváth, E.; Ferincz, Á.; Kakasi, B.; Nagy, S.T.; Imre, K.; Paulovits, G.: Eco- and genotoxicity profiling of a rapeseed biodiesel using a battery of bioassays. Ecotoxicol. Environ. Safety, 2018, 151, 170-177 DOI: 10.1016/j.ecoenv.2018.01.015

[22] Leite, M.B.N.L.; de Araújo, M.M.S.; Nascimento, I.A.; da Cruz, A.C.S.; Pereira, S.A.; do Nascimento, N.C.: Toxicity of water-soluble fractions of biodiesel fuels derived from castor oil, palm oil, and waste cooking oil. Environ. Toxicol. Chem., 2011, 30(4), 893-897 DOI: 10.1002/etc.444

[23] Müller, J.B.; Melegari, S.P.; Perreault, F.; Matias, W.G.: Comparative assessment of acute and chronic ecotoxicity of water soluble fractions of diesel and biodiesel on Daphnia magna and Alivivibrio fischeri. Chemosphere, 2019, 221, 640-646 DOI: 10.1016/j.chemosphere.2019.01.069

[24] Hollebone, B.P.; Fieldhouse, B.; Landriault, M.; Doe, K.; Jackman, P.: Aqueous solubility, dispersibility and toxicity of biodiesels, in International oil spill conference proceedings, Savannah, USA, 2008. DOI: 10.7901/2169-3358-2008-1-929

[25] Tjarinto, R.; Rachmatiah, I.; Salami, S.: Toxicity test of water-soluble fractions of waste vegetable oil-based biodiesel and biodiesel/diesel blends on Daphnia magna and Allium cepa. in: Proceedings of the 3rd Applied Science for Technology Innovation, ASTECHNOVA International Energy Conference, Yogyakarta, Indonesia, 2014, 294-301

[26] Heger, S.; Du, M.; Bauer, K.; Schäffer, A.; Hollert, H.: Comparative ecotoxicity of potential biofuels to water flea (Daphnia magna), zebrafish (Danio rerio) and Chinese hamster (Cricetulus griseus) V79 cells. Sci. Total Environ., 2018a, 631-632, 216-222 DOI: 10.1016/j.scitotenv.2018.03.028

[27] Heger, S.; Bluhm, K.; Du, M.; Lehmann, G.; Anders, N.; Dechambrec, D.; Bardowc, A.; Schäfferdef, A.; Hollert, H.: Aquatic toxicity of biofuel candidates on Daphnia magna. Ecotoxicol. Environ. Safety, 2018b, 164, 125-130 DOI: 10.1016/j.ecoenv.2018.08.008
[28] Yang, Y.: Life cycle freshwater ecotoxicity, human health cancer, and noncancer impacts of corn ethanol and gasoline in the U.S., J. Clean. Prod., 2013, 53, 149-157 DOI: 10.1016/j.jclepro.2013.04.009

[29] Bunzel, K.; Schäfer, R.B.; Thrän, D.; Kattwinkel, M.: Pesticide runoff from energy crops: A threat to aquatic invertebrates? Sci. Total Environ., 2015, 537, 187-196 DOI: 10.1016/j.scitotenv.2015.08.011

[30] Camargo, R.P.L.; Carrim, A.J.I.; Filho, N.R.A.: Study ecotoxicity of biodiesel from residual oils and fats and the effects of salinity aquatic ecosystems. Ecotoxicol. Environ. Contam., 2017, 12(1), 63-67 DOI: 10.5132/eec.2017.01.08

[31] Gateau, P.; van Dievoet, F.; Bouillon, V.; Vermeersch, G.; Claude, S.; Staat, F.: Environmentally friendly properties of vegetable oil methyl esters. J. Am. Oil Chem. Soc., 2005, 12(4), 308-313 DOI: 10.1051/ocl.2005.0308

[32] LeBlanc, G.A.: Acute toxicity of priority pollutants to water flea (Daphnia magna). Bull. Environ. Contam. Toxicol., 1980, 24(1), 684-691 DOI: 10.1007/bf01608174

[33] Kühn, R.; Pattard, M.; Pernak, K.D.; Winter, A.: Results of the harmful effects of selected water pollutants (anilines, phenols, aliphatic compounds) to Daphnia magna. Water Res., 1989, 23(4), 495-499 DOI: DOI: 10.1016/0043-1354(89)90141-3

[34] Bluhm, K.; Heger, S.; Seiler, T.B.; Hallare, A.V.; Schaeffer, A.; Hollert, H.: Toxicological and ecotoxicological potencies of biofuels used for the transport sector -a literature review. Energy Environ. Sci., 2012, 5, 7381-7392 DOI: 10.1039/c2ee03033k

[35] Pedersen, F.; Petersen, G.I.: Variability of species sensitivity to complex mixtures. Water Sci. Technol., 1996, 33(6), 109-119 DOI: 10.1016/02731223(96)00318-6

[36] Pintar, A.; Besson, M.; Gallezot, P.; Gibert, J.; Martin, D.: Toxicity to Daphnia magna and Vibrio fischeri of Kraft bleach plant effluents treated by catalytic wet-air oxidation. Water Res., 2004, 38(2), 289-300 DOI: 10.1016/j.watres.2003.09.027

[37] Czech, B.; Jośko, I.; Oleszczuk, P.: Ecotoxicological evaluation of selected pharmaceuticals to Vibrio fischeri and Daphnia magna before and after photooxidation process. Ecotoxicol. Environ. Safety, 2014, 104, 247-253 DOI: 10.1016/j.ecoenv.2014.03.024

[38] Brack, W.; Aissa, S.A.; Backhaus, T.; Dulio, V.; Escher, B.I.; Faust, M.; Hilscherova, K.; Hollender, J.; Hollert, H.; Müller, C.; Munthe, J.; Posthuma, L.; Seiler, T.B.; Slobodnik, J.; Teodorovic, I.; Tindall, A.J.; de Aragăo Umbuzeiro, G.; Zhang, X.; Altenburger, R.: Effect-based methods are key. The European Collaborative Project SOLUTIONS recommends integrating effect-based methods for diagnosis and monitoring of water quality. Environ. Sci. Eur., 2019, 31, 10 DOI: 10.1186/s12302-019-0192-2

[39] Marzullo, R.C.M.; Matai, P.H.L.S.; Morita, D.M.: New method to calculate water ecotoxicity footprint 
of products: A contribution to the decision-making process toward sustainability. J. Clean. Prod., 2018, 188, 888-899 DOI: 10.1016/j.jclepro.2018.03.307

[40] Jos, A.; Repetto, G.; Rios, J.C.; Hazen, M.J.; Molero, M.L.; Peso, A.; Salguero, M.; FernándezFreire, P.; Pérez-Martín, J.M.; Cameán, A.: Ecotoxicological evaluation of carbamazepine using six dif- ferent model systems with eighteen endpoints. Toxicol. In Vitro, 2003, 17, 525-532 DOI: 10.1016/S08872333(03)00119-X

[41] Manusadžianas, L.; Sadauskas, K.; Vitkus, R.: Comparative study of indices used in toxicity evaluation of effluents. Desalination, 2010, 250, 383-389 DOI: 10.1016/J.DESAL.2009.09.061 